\title{
Rancang Bangun Alat Penyiram Sayuran Hidroponik Menggunakan Arduino Mega 2560
}

\author{
Bayu Kusumo ${ }^{1, *}$, Nur Azis ${ }^{2}$ \\ ${ }^{1}$ Teknologi Industri, Teknik Elektro, Universitas Jayabaya, Jakarta, Indonesia \\ ${ }^{2}$ Teknik, Sistem Informasi, Universitas Krisnadwipayana, Jakarta, Indonesia \\ Email: 1,*Bayu.kusumo062@gmail.com, ${ }^{2}$ nuraziz@unkris.ac.id. \\ Email Penulis Korespondensi: Bayu.kusumo062@gmail.com
}

\begin{abstract}
Abstrak- Kegiatan cocok tanam dengan sistem hidroponik di tengah pendemi covid 19 banyak diminati dengan memanfaatkan lahan yang terbatas. Salah satu unsur dalam kegiatan cocok tanam adalah air, karena 70 persen molekul yang ada di tanaman adalah air. Air berfungsi sebagai bahan baku tanaman dalam proses fotosintesis dan juga dapat menjaga kelembaban tumbuhan agar tidak layu. Saat ini Metode penyiraman tanaman masih dilakukan secara manual dengan cara mengecek kondisi tanah, jika kondisi tanah kering maka pompa air baru dinyalakan untuk penyiraman. Namun metode tersebut dirasa kurang efektif karena mengharuskan petani melakukan pengecekan rutin dan tidak boleh lupa agar tanah tidak kering sehingga tanaman tidak layu. Untuk menjawab permasalahan tersebut dalam penelitian ini ingin memberikan kepastian bagaimana tanaman tersebut mendapatkan air yang cukup. Salah satu usaha yang dapat dilakukan adalah dengan membuat alat penyiraman otomatis yang tanpa harus menyita waktu sehingga memberikan dampak yang efisien. Alat yang dibuat mengunakan Komponen Arduino Mega 2560 yang berfungsi untuk pengontrol dalam system penyiraman dengan bantuan smartphone untuk kontrol jarak jauh.
\end{abstract}

Kata Kunci: Hidroponik; Covid 19; Air; Arduino; Smartphone

Abstract-Activities suitable for planting with hydroponic systems in the midst of covid 19 pendemi are in great demand by utilizing limited land. One of the elements in suitable planting activities is water, because 70 percent of the molecules in plants are water. Water serves as the raw material of plants in the process of photosynthesis and can also keep plant moisture from withering. Currently the method of watering plants is still done manually by checking the condition of the soil, if the soil condition is dry then the new water pump is turned on for watering. But the method is considered less effective because it requires farmers to do regular checks and should not forget so that the soil does not dry so that the plants do not wither. To answer these problems in this study want to provide certainty how the plant gets enough water. One of the efforts that can be done is to make an automatic watering tool that without having to take time so as to give an efficient impact. The tool is made using Arduino Mega 2560 Components that serve as controllers in the watering system with the help of smartphones for remote control.

Keywords: Hydroponics; Covid 19; Water; Arduino; Smartphone

\section{PENDAHULUAN}

Penyebaran virus Corona yang telah meluas ke berbagai belahan dunia membawa dampak pada perekonomian Indonsia, baik dari sisi perdagangan, investasi dan pariwisata [1]. Merespon pandemi Corona Virus Disease 2019 (Covid-19), pemerintah Indonesia mulai menerapkan pembatasan dengan kebijakan social distancing (jaga jarak sosial, menghindari kerumunan), lalu physical distancing (jaga jarak antar orang minimal 1,8 meter) sejak awal Maret 2020 [2]. Kebijakan tersebut, membuat beberapa perusahaan mengambil langkah untuk mengurangi kerugian akibat Covid-19. Salah satu langkah yang diambil oleh beberapa perusahaan di Indonesia yaitu harus melakukan Pemutusan Hubungan Kerja (PHK) pada para karyawan yang bekerja di perusahaan tersebut [3]. hal tersebut secara langsung berdampak terhadap sempitnya lapangan kerja yang tersedia sehingga menyebabkan terjadinya pengangguran dan ketimpangan distribusi pendapatan yang akan membawa masalah yang lebih besar lagi [4]. Untuk menyiasati kebutuhan akan pangan salah satunya adalah dengan bercocok tanam. Lahan perkarangan memiliki potensi dalam penyediaan bahan pangan bagi keluarga, sehingga pengeluaran rumah tangga untuk membeli bahan pangan dapat dikurangi dan meningkatkan pendapatan rumah tangga jika produksi bahan pangan berlimpah terutama sayur-sayuran yang higienis dan sehat bagi keluarga[5].

Kebanyakan orang mungkin berpikir bahwa tanpa lahan yang luas dan cukup, mereka tidak akan bisa untuk menanam sayuran[6] Pekarangan rumah di komplek perumahan perkotaan umumnya memiliki lahan terbuka yang sempit dan halamannya didominasi oleh paving block atau lantai semen[7]. sistem hidroponik yang paling tepat untuk model usaha pertanian dengan lahan terbatas[8]. Pertanian dengan menggunakan sistem hidroponik tidak memerlukan lahan yang luas, tetapi dalam bisnis pertanian layak dipertimbangkan karena dapat dilakukan di pekarangan, rumah, atap rumah, maupun lahan lainnya[9]. namun dalam bercocok tanam ada hal lain yang menjadi pertimbangan selain lahan yaitu air. Dalam penelitian terdahulu yang dilakukan oleh Gunawan, Marliana Sari[10], Chusniati Dhonny, Widodo[11] dan Rudi Budi Agung dkk [12] yang membedakan didalam penelitian ini dengan penellitian ini adalah jenis tanaman dan komponen yang dijadikan sebagai alat pembangun dipenelitian akan diteliti bagaimana cara pendistribusian air atau penyiraman otomatis dengan bantuan Arduino Mega 2560 dan ponsel cerdas berbasis Android.

Arduino adalah sebuah sebuah kit atau papan elektronik yang dilengkapi dengan software open source yang menggunakan keluarga mikrokontroler ATMega dan berfungsi sebagai pengendali mikro single-board yang dirancang untuk memudahkan penggunaan elektronik dalam berbagai bidang yang dirilis oleh Atmel[13] Ponsel cerdas (bahasa Inggris: smartphone) adalah telepon genggam yang mempunyai kemampuan dengan pengunaan 
JURNAL MEDIA INFORMATIKA BUDIDARMA

Volume 5, Nomor 1, Januari 2021, Page 124-128

ISSN 2614-5278 (media cetak), ISSN 2548-8368 (media online)

Available Online at https://ejurnal.stmik-budidarma.ac.id/index.php/mib

DOI 10.30865/mib.v5i1.2584

dan fungsi yang menyerupai komputer. [14] Android adalah sebuah sistem operasi perangkat mobile berbasis linux yang mencangkup sistem operasi, middleware dan aplikasi[15]

\section{METODOLOGI PENELITIAN}

\subsection{Tahapan Penelitian}

Studi perencanaan Pembuatan aplikasi dilakukan melalui beberapa tahapan proses mulai dari awal sampai dengan selesai, seperti ditunjukan pada gambar 1. Adapun langkah - langkah atau prosedur dalam penelitian ini adalah :
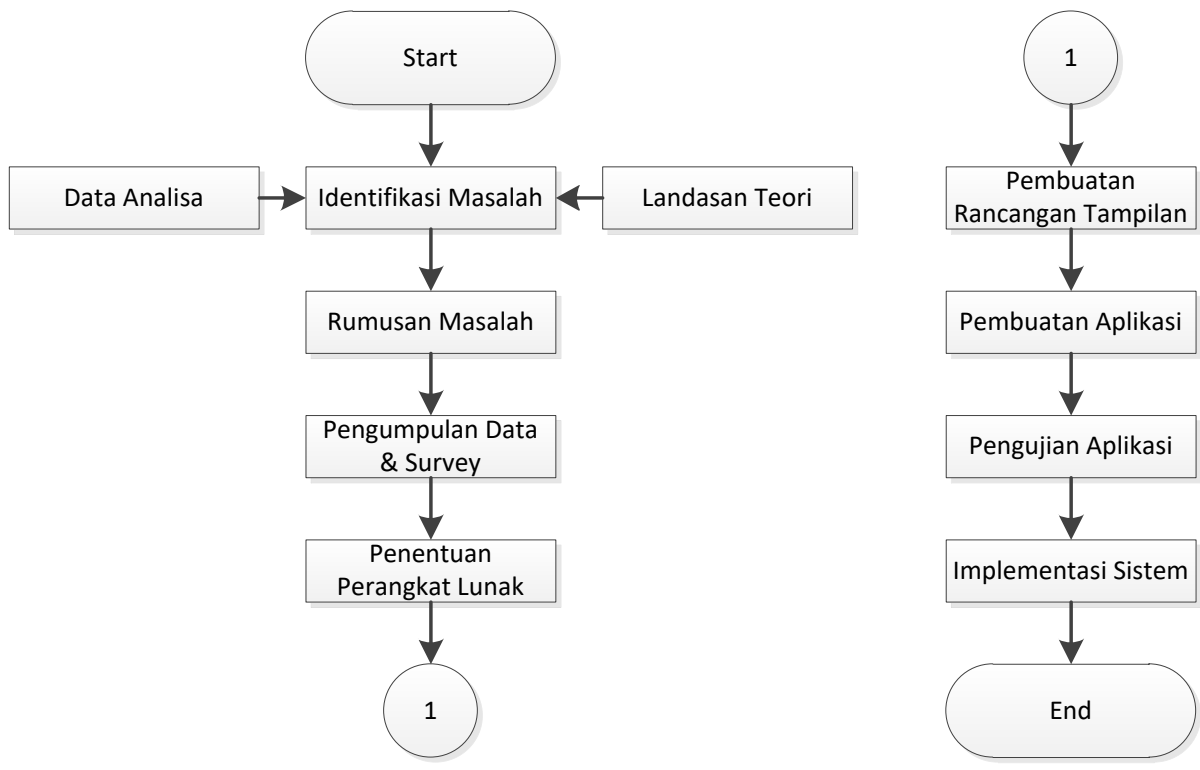

Gambar 1. Diagram Alir Penelitian

Penjelasan gambar 1 Diagram Alir Penelitian :

a. Tahap Identifasi Masalah

Pada tahap ini penelitian difokuskan dengan mencari hal-hal yang berkatian dengan tanaman kangkung serta penyebab atau akar masalah dari pokok penelitian dengan mempelajari penelitian-penelitian yang menyerupai.

b. Tahap Perumusan Masalah

Pada tahap ini peneliti merumusakan masalah-masalah yang di dapat dari kendala dalam penyiraman tanaman

c. Tahap Pengumpulan Data dan Survei

Pada tahapan ini peneliti melakukan observasi kelapangan mencari data-data pendukung penelitian, wawancara Ibu-ibu PKK di wilayah sekitar.

d. Tahap Penentuan Perangkat keras

Pada tahapan ini peneliti melakukan analisa dan mencari alat-alat apa yang dapat medukung penelitian serta dapat diimplementasikan dengan studi kasus yang diteliti

e. Tahap Penetuan Perangkat Lunak

Pada tahap ini peneliti melakukan analisa dan mencari aplikasi yang dapat dijadikan sebagai bahan informasi untuk penelitian dan cocok dengan alat yang digunakan

f. Tahap Merancangan Alat

Pada tahap ini peneliti melakukan pembangunan alat yang akan digunakan untuk mendukung penelitian

g. Tahap Perancangan Tampilan Aplikasi

Pada tahap ini peneliti merancang tampilan user interface yang disesuaikan dengan kondisi dilapangan.

h. Tahapan Pembuatan Aplikasi

Pada tahap ini peneliti membuat aplikasi yang berfungsi untuk informasi pengukuran dan memantau kelembaban, suhu dan tingkat ketinggian air

i. $\quad$ Tahap Pengujian Alat \& Aplikasi

Pada tahap ini dilakukan pengujian terhadap alat yang dirancang berserta aplikasi yang dibuat apakah dapat bekerja sesuai yang diharapkan atau tidak disamping itu juga dilakukan uji coba.

j. $\quad$ Tahap Implementasi

Pada tahap ini alat dan aplikasi diterapkan di sekitar lahan tempat bercocok tanam setelah sebelumnya dilakukan pengujian, dan juga pada tahap ini akan dilakukan pemantauan tentang keberhasilan atau keefektifan dari alat yang dibangun serta aplikasi yang dibuat. 


\section{HASIL DAN PEMBAHASAN}

Alur kerja sistem dapat dijelaskan pada diagram alur yang dimulai dengan mengukur kelembaban tanah apakah kurang dari ambang batas jika kurang maka selanjutnya alat melakukan penyiraman. Untuk diagram alirnya dapat dilihat pada gambar 2 .

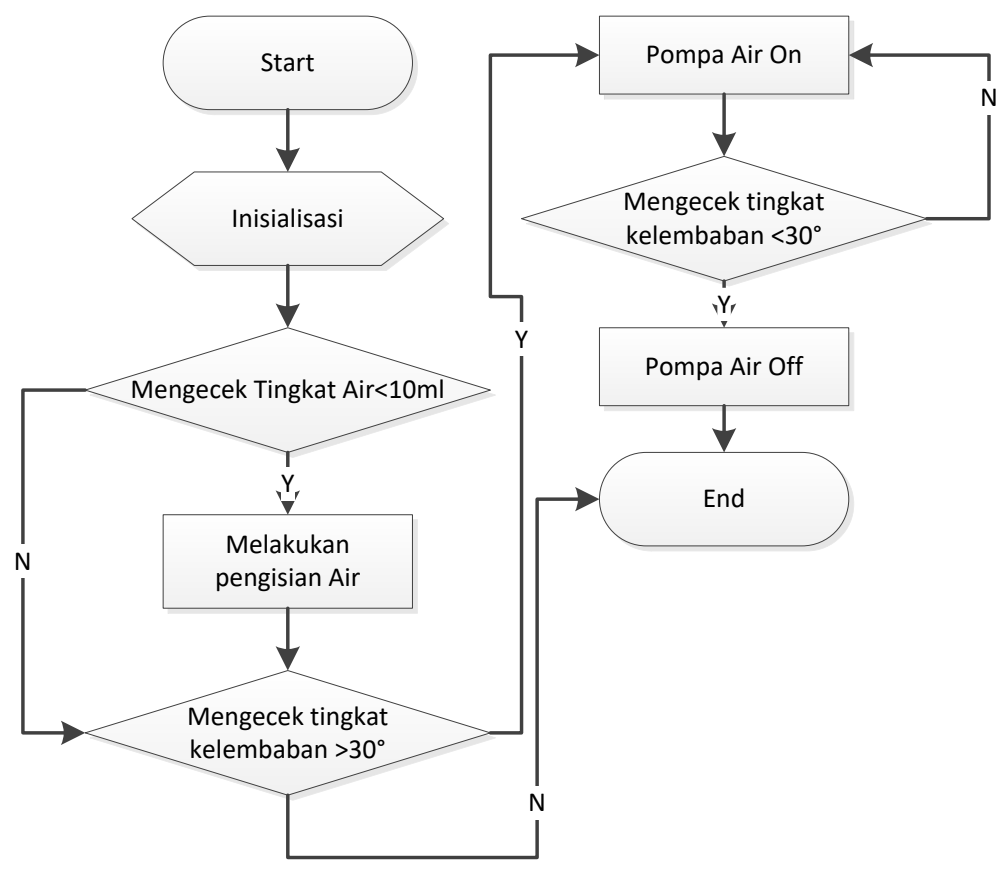

Gambar 2. Diagram Alur Sistem

Pada gambar 2. diagram alur sistem yaitu dimulai dari mengecek tingkat air, jika tingkat air $<10 \mathrm{ml}$ maka harus melakukan pengisian air sampai penuh dan sedangkan jika tingkat air $>10 \mathrm{ml}$ maka akan langsung melakukan pengecekan kelembaban tanah. Apabila tingkat air yang $<10 \mathrm{ml}$ sudah mengisi air sampai penuh kemudian dilakukan pengecekan suhu, jika suhu $>30^{\circ}$ pompa air akan on dan akan langsung melakukan penyiraman secara otomatis dan setelah suhu $<30^{\circ}$ maka pompa air akan berhenti dan proses penyiraman selesai.

\subsection{Rangkaian Perangkat Keras.}

Instalasi perangkat keras merupakan suatu proses instalasi alat atau perakitan alat yang digunakan dalam membangun sistem Penyiraman Tanaman Otomatis berbasis Android. Adapun rangkaian perangkat keras terlihat pada gambar 3.

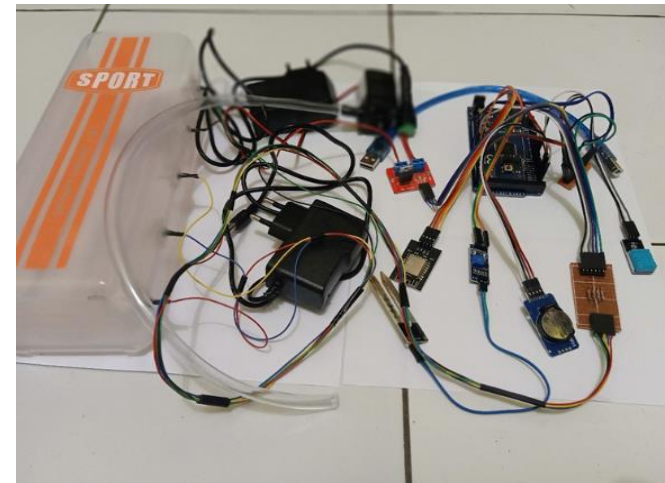

Gambar 3. Rangkaian Perangkat Keras.

Pada gambar 3 wifi dan sensor terhubung dengan arduino dan Ethernet Shield. Selain itu pompa air terhubung ke adaptor dengan arus listrik, adapun adaptor sebagai daya utama untuk menghidupkan Arduino sebagai sistem utama

\subsection{Tampilan Pengujian}

Pada gambar 4 adalah tampilan realtime dimana ada keterangan dari mulai suhu sampai dengan ketinggian air di waktu yang sebenarnya atau keadaan saat itu juga. 
JURNAL MEDIA INFORMATIKA BUDIDARMA

Volume 5, Nomor 1, Januari 2021, Page 124-128

ISSN 2614-5278 (media cetak), ISSN 2548-8368 (media online)

Available Online at https://ejurnal.stmik-budidarma.ac.id/index.php/mib

DOI 10.30865/mib.v5i1.2584
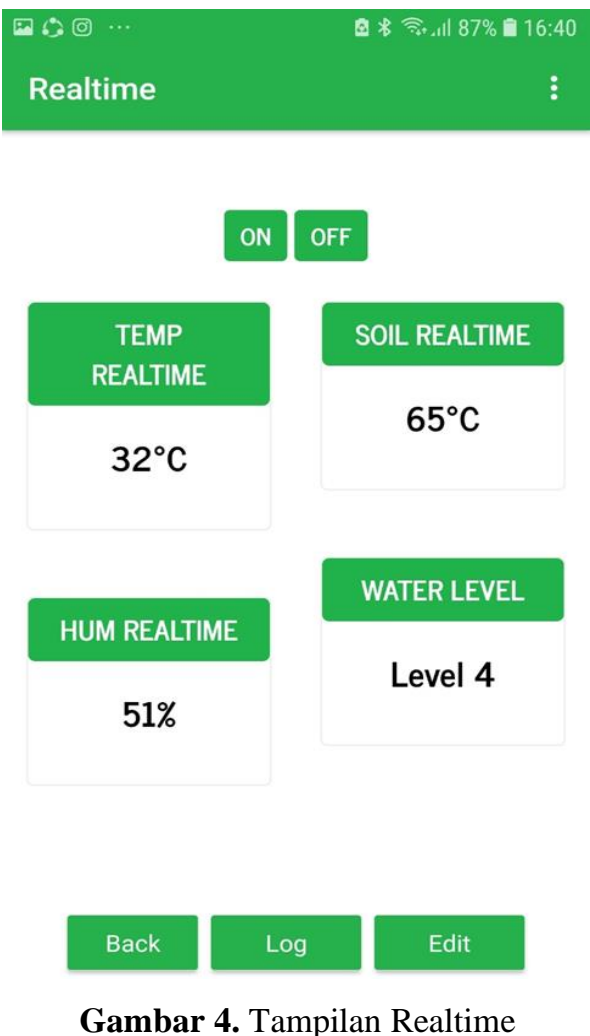

Pada gambar 5 adalah keterangan dimana ada waktu, suhu dan kelembaban udara, kelembaban tanah, water level dan status pompa. Keterangan pada gambar dibawah dimana suhu sekarang menentukan $31^{\circ}$, kelembaban udara menentukan 52\%, kelembaban tanah menentukan disetiap waktu berubah-ubah karena sudah otomatis menyesuaikan dengan kondisi tanah dan selain itu juga menentukan ketinggan air ada di level 0 dan kondisi pompa air masih off.

\begin{tabular}{|c|c|c|c|c|c|}
\hline \multicolumn{2}{|c|}{$\begin{array}{l}\text { Log Activity } \\
\text { Log A }\end{array}$} & \multicolumn{4}{|c|}{$\begin{array}{r}\Delta * \text { ลे, } 11 \text { 87\% } 16: 40 \\
\vdots\end{array}$} \\
\hline Time & Temp & Hum & Soil & WL & Pump \\
\hline $16: 40: 28$ & 33 & 52 & 65 & $\begin{array}{l}\text { Level } \\
4\end{array}$ & Off \\
\hline $16: 40: 22$ & 33 & 52 & 65 & $\begin{array}{l}\text { Level } \\
4\end{array}$ & On \\
\hline $16: 40: 20$ & 33 & 52 & 66 & $\begin{array}{l}\text { Level } \\
4\end{array}$ & Off \\
\hline $16: 40: 16$ & 33 & 52 & 64 & $\begin{array}{l}\text { Level } \\
4\end{array}$ & Off \\
\hline $16: 40: 12$ & 33 & 52 & 68 & $\begin{array}{l}\text { Level } \\
4\end{array}$ & Off \\
\hline
\end{tabular}

\section{Back}

Gambar 5. Tampilan Interface Log Activity 
JURNAL MEDIA INFORMATIKA BUDIDARMA

Volume 5, Nomor 1, Januari 2021, Page 124-128

ISSN 2614-5278 (media cetak), ISSN 2548-8368 (media online)

Available Online at https://ejurnal.stmik-budidarma.ac.id/index.php/mib DOI 10.30865/mib.v5i1.2584

Pada gambar 6 adalah output yang tampil pada layar aplikasi smartphone bahwa kondisi air pada tangki hampir habis. Informasi ini berfungsi sebagai pemberitahuan untuk melakukan pengisian pada tangki air penampung.

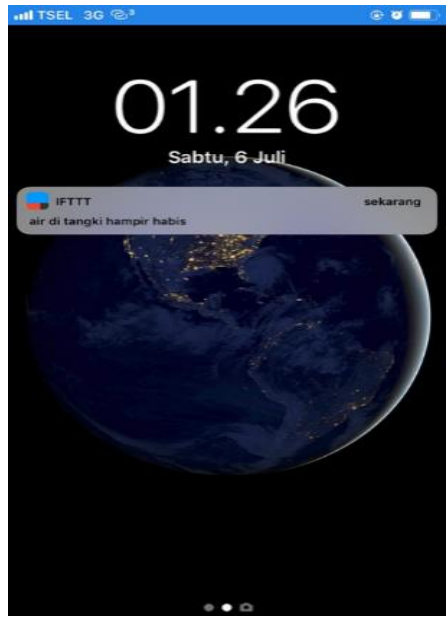

Gambar 6. Output Kondisi Air pada tangki

Pada gambar 7 adalah tampilan proses penyiraman yang dilakukan dengan kondisi tanah dengan suhu $>30^{\circ}$ dan alat berfungsi secara baik.

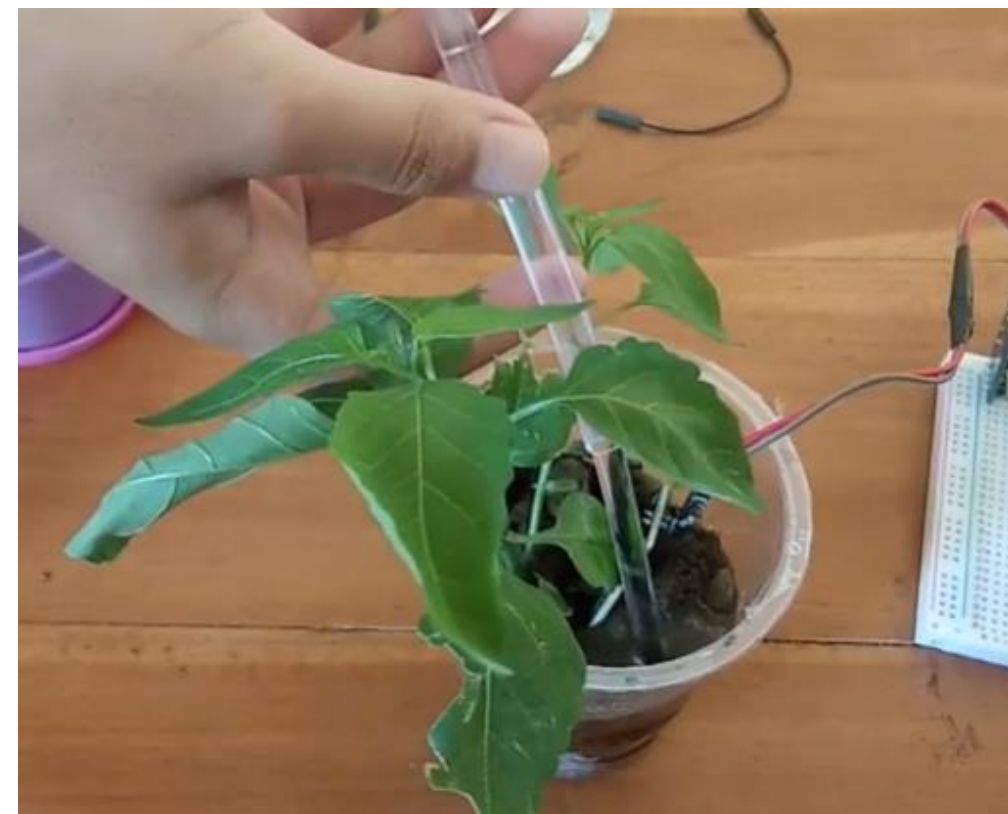

\section{KESIMPULAN}

Dilihat dari hasil dan pembahasan yang dibahas pada bab sebelumnya, terlihat pada gambar 4 bahwa keadaan suhu sampai dengan ketinggian air dapat terlihat secara realtime pada layar smartphone. Hal tersebut terlihat juga pada gambar 5. Pada gambar 6 proses penyiram dapat dilakukan dengan baik dengan mengunakan alat serta aplikasi yang dibangun. Berdasarkan hal tersebut dapat disimpulkan bahwa alat yang dibuat terkoneksi baik dengan smartphone dan berfungsi secara optimal.

\section{REFERENCES}

[1] D. A. D. Nasution, E. Erlina, and I. Muda, "Dampak Pandemi COVID-19 terhadap Perekonomian Indonesia," J. Benefita vol. 5, no. 2, p. 212, 2020, doi: 10.22216/jbe.v5i2.5313.

[2] W. Hadiwardoyo, "Kerugian Ekonomi Nasional Akibat Pandemi Covid-19," Baskara J. Bus. Enterpreneursh., vol. 2, no. 2, pp. 83-92, 2020, doi: 10.24853/baskara.2.2.83-92.

[3] I. N. Juaningsih, “Analisis Kebijakan PHK Bagi Para Pekerja Pada Masa Pandemi Covid-19 di Indonesia,” Bul. Huk. dan Keadilan, vol. 4, no. 1, pp. 189-196, 2020.

[4] Yasrizal and I. Hasan, "Pengaruh Pembangunan Sektor Pertanian Terhadap Distribusi Pendapatan Dan Kesempatan Kerja Di Indonesia," J. Ilmu Ekon. dan Pembang., vol. 16, no. 1, 2017, doi: 10.20961/jiep.v16i1.2320. 
JURNAL MEDIA INFORMATIKA BUDIDARMA

Volume 5, Nomor 1, Januari 2021, Page 124-128

ISSN 2614-5278 (media cetak), ISSN 2548-8368 (media online)

Available Online at https://ejurnal.stmik-budidarma.ac.id/index.php/mib

DOI 10.30865/mib.v5i1.2584

[5] N. Hidayati, P. Rosawanti, F. Arfianto, and N. Hanafi, "PEMANFAATAN LAHAN SEMPIT UNTUK BUDIDAYA SAYURAN DENGAN SISTEM VERTIKULTUR,” PengabdianMu, vol. 53, no. 9, pp. 1689-1699, 2019.

[6] A. Masduki, "Hidroponik Sebagai Sarana Pemanfaatan Lahan,” J. Pemberdaya., vol. 1, no. 2, pp. 185-192, 2017.

[7] H. Gustia, Rosdiana, and Junaidi, "Budidaya Tanaman Sayuran pada Lahan Pekarangan dengan Teknik Vertikultur dan Hidroponik," Pros. Semin. Nas. Pengabdi. Masy. LPPM UMJ, vol. 1, no. September 2019, pp. 1-6, 2019.

[8] I. S. Roidah, "Pemanfaatan Lahan Dengan Menggunakan Sistem Hidroponik," vol. 1, no. 2, pp. 43-50, 2014.

[9] S. Hidayat, Y. Satria, and N. Laila, "Penerapan Model Hidroponik Sebagai Upaya," J. Graha Pengabdi., vol. 2, no. 2 , pp. 141-148, 2020.

[10] G. sari merliana, "Rancang Bangun Alat Penyiram Tanaman Otomatis Menggunakan Sensor Kelembaban Tanah," $J$. Electr. Technol., vol. 3, no. 1, pp. 13-17, 2018.

[11] W. Chusniati Dhonny, "RANCANG BANGUN SISTEM PENYIRAMAN TANAMAN ANGGREK DENDROBIUM MENGGUNAKAN SENSOR SHT11 PADA FASE PEMBUNGAAN Chusniati Dhonny 1) dan Widodo 1) 1)," vol. 15, pp. 51-60, 2017.

[12] R. B. Agung, M. Nur, and D. Sukayadi, "Menggunakan Sensor Kelembaban Tanah Berbasis Micro Contoller Atmega 328," Cerita, vol. 5, no. 1, pp. 97-106, 2019.

[13] A. Iskandar, M. Muhajirin, and L. Lisah, "Sistem Keamanan Pintu Berbasis Arduino Mega," J. Inform. Upgris, vol. 3 , no. 2, pp. 99-104, 2017, doi: 10.26877/jiu.v3i2.1803

[14] N. Azis, M. S. Hartawan, and S. Amelia, "Rancang Bangun Otomatisasi Penyiraman dan Monitoring Tanaman Kangkung Berbasis Android," J. IKRA-ITH Inform., vol. 4, no. 3, pp. 95-102, 2020.

[15] N. Azis, G. Pribadi, and M. S. Nurcahya, "Analisa dan Perancangan Aplikasi Pembelajaran Bahasa Inggris Dasar Berbasis Android,” J. IKRA-ITH Inform., vol. 34, no. 4, pp. 101-108, 2020. 